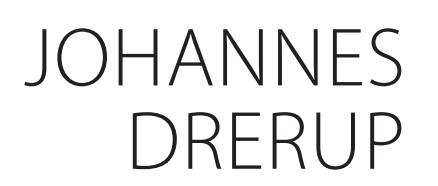

\title{
Global Citizenship Education, Global Educational Injustice and the Postcolonial Critique
}

\begin{abstract}
This contribution develops a defence of a universalist conception of Global Citizenship Education (GCE) against three prominent critiques, which are, among others, put forward by postcolonial scholars. The first critique argues that GCE is essentially a project of globally minded elites and therefore expressive both of global educational injustices and of the values and lifestyles of a particular class or milieu. The second critique assumes that GCE is based on genuinely 'Western values' (e.g., in the form of a conception of human rights or conceptions of rationality or the self), which are neither universally accepted nor universally valid and therefore unjustly forced on members of non-Western cultures and societies. GCE, according to this critique, is assumed to be another version of the educational justification of a hegemonic and unjust global Western regime. The third critique focuses on the epistemological preconditions of GCE. It assumes that GCE relies on a particular, culturally embedded 'Western epistemology,' which perpetuates historically grown global educational and epistemic injustices by dominating and subjugating alternative epistemological approaches. With respect to the first critique I argue that it is to a certain extent sociologically plausible, but wrong when it is applied to the educational and political legitimacy of GCE. The second critique overestimates the consensus within the 'Western tradition' and underestimates the transnational dissemination of universalist ideals and values as well as its own reliance on universalist validity claims. I argue that in order to provide a plausible criticism of historically grown global educational and political injustices, it is imperative for GCE to integrate central insights provided by the postcolonial critique, without giving up on universalist ideals and values. The third critique is, according to my argumentation, based on flawed epistemological assumptions, which do not withstand critical scrutiny. Instead of identifying epistemic and scientific claims as the expressions of a particular 'culture' or geographical location (the 'West'), I defend the position that philosophical and scientific research should ideally be conceived as a democratic and universalist project, whose emancipatory potential can only be realized on the basis of a universalist epistemology.
\end{abstract}

Keywords: Global Citizenship Education; global educational justice; postcolonial studies; universalism; elites.

\section{Introduction}

'The idea that despotism of any kind was an offence against humanity, had crystallized into an instinctive feeling, and modern morality and sentiment revolted against the enslavement of nation by nation, of class by class or of man by man. Imperialism had to justify itself to this modern sentiment and could only do so by pretending to be a trustee of liberty, commissioned from on high to civilize the uncivilized and train the untrained until the time had come when the benevolent conqueror had done his work and could unselfishly retire. Such were the professions with which England justified her usurpation 


\section{GLOBAL CITIZENSHIP EDUCATION, GLOBAL EDUCATIONAL INJUSTICE AND THE POSTCOLONIAL CRITIQUE}

of the heritage of the Moghul and dazzled us into acquiescence in servitude by the splendour of her uprightness and generosity. Such was the pretence with which she veiled her annexation of Egypt. These Pharisaic pretensions were especially necessary to British imperialism because in England the Puritanical middle class had risen to power and imparted to the English temperament a sanctimonious self-righteousness which refused to indulge in injustice and selfish spoliation except under the cloak of virtue, benevolence and unselfish altruism' (Aurobindo Ghose, cited in: Mishra, 2013: 223). ${ }^{1}$

Aurobindo Ghose's criticism of the ideological agenda of the British Empire points to a central element in the historical justifications of colonialism and imperialism $^{2}$ : both were in many cases justified by resorting to paternalist and educational arguments and rationales. The colonized, as was argued, for instance, by liberal thinkers such as James and John Stuart Mill, were not regarded as capable of governing themselves and therefore needed the colonizers as benevolent representatives, at least for a certain period of time. Like children, they were to be civilized, trained and educated to finally become autonomous and self-governing agents (McCarthy, 2009; Arneil, 2012). An 'advanced Western education' justified the superiority of 'Western culture' and the legitimacy of the colonial project. This mode of justifying and metaphorically framing the relationship between colonizers and colonized was still used in the 2oth century and is still relevant in today's postcolonial world (Hobson, 2017; Barnett, 2017; Liebel, 2017). Superiority is today usually no longer justified with reference to straightforward racist arguments, but by constructing cultural, epistemic and also educational differences. The right kind of education and the right kind of childhood, according to this way of thinking, is a 'Western' education and a 'Western' conception of childhood. Colonialism and imperialism ${ }^{3}$ thus were in many cases also educational projects with respect to their justification (at least at an ideological level) and with respect to their concrete educational practices and institutions in the colonies (Castro Varela, 2016). The effects of both can be still felt around the world today, for instance, in the manifestation of the globalization of Western-style education and schooling.

In turn, there are ample reasons to remain sceptical when it comes to contemporary conceptions of education, which claim to foster capacities, dispositions and knowledge that are supposed to be necessary for children to

1 Aurobindo Ghose is arguably one of the most important Indian philosophers of the 2oth century; see, for instance: Heehs, 2008.

2 For a historical overview of ideological justifications of the British Empire in the 18th and 19th centuries, see: Pitts, 2005 .

3 One way to understand the relation between colonialism and imperialism is to assume that imperialism 'can function without formal colonies (as in United States imperialism today) but colonialism cannot' (Loomba, 2015: 28); for another discussion on the distinction, see also: Castro Varela and Dhawan, 2015. 
become 'global citizens' - especially when they are defended by scholars who are based in Western European countries. The suspicion immediately suggests that, under the benevolent and seemingly innocent cloak of what is today called 'Global Citizenship Education' (GCE), a new form of educational imperialism is promoted and forced on the rest of the world. Thus, it seems that GCE, albeit in many cases officially geared towards the fight for global justice, is itself the expression and perpetuation of historically grown global educational and political injustices and power hierarchies.

In this contribution, I will develop a defence of the universalist conception of GCE against some prominent postcolonial critiques. ${ }^{4}$ Even though I am generally sympathetic with some of the central educational, ethical as well political aims defended by postcolonial critiques, I am sceptical concerning the particularist claims that in some cases tend to go along with these critiques. I will argue that a critical conception of GCE can incorporate most of the legitimate concerns put forward by postcolonial scholars and that, as a global project, GCE can and should be understood as a central means to foster global justice in and through education. ${ }^{5}$

After a short introduction on the central conceptual and normative elements of the universalist conception of GCE on which my argument relies, I will reconstruct and discuss three prominent critiques, which have been made against GCE. The first critique argues that GCE is essentially a project of globally minded elites and therefore expressive both of global educational injustices and of the values and lifestyles of a particular class or milieu. The second critique assumes that GCE is based on genuinely Western and liberal values (e.g., in the form of a conception of human rights or conceptions of rationality or the self), which are neither universally accepted nor universally valid and therefore unjustly forced on members of non-Western cultures and societies. GCE,

4 According to Andreotti, postcolonialism is primarily concerned with 'the epistemic violence of colonialism and the interrogation of European cultural supremacy in the subjugation of different peoples and knowledges in colonial and neocolonial contexts' (Andreotti, 2010: 238). Loomba assumes that postcolonial studies is 'not a tightly bound 'field' as such' (Loomba, 2015: 3) and points to the dangers of stretching the concept of 'postcolonial' (ibid.: 34). In what follows I will use the terms 'postcolonial' and 'decolonial' interchangeably, because it remains unclear whether there is a real difference between both approaches. Decolonial scholars criticised, among others, that postcolonial scholars' critiques of Western epistemology were themselves based on a Eurocentric and Western epistemology (see: Varela and Dhawan, 2015: 320). I am aware of the fact that 'postcolonialism' (and also GCE) covers a huge variety of differing approaches. My critique of postcolonial critiques thus (obviously) does not claim to cover all postcolonial conceptions and approaches. It should also be noted that a universalist conception of GCE is criticised not just by postcolonial scholars, but also - usually for different reasons - by nationalists or statists.

5 In what follows, my approach to global educational justice will not primarily consist of a 'globalization' of the debate on educational justice, which usually focuses on a national context. Thus, I will not focus on the traditional concerns of educational justice, such as adequacy vs. equality of opportunity, equality of what etc., but rather on some questions about global educational justice, which are relevant to conceptions of education that have a global dimension (such as GCE; see the third section). Nevertheless, it should be noted that, at a global level, I think that a combination of an adequacy principle and a principle of equality of opportunity provides the most suitable and relevant standards of educational justice. Moreover, I am minded that the former should be spelled out as a conception of general education, which in the future may lead to the formulation of a world curriculum. I believe that every child has right to acquire the capacities, dispositions and knowledge necessary to become a global citizen in this sense. 
according to this critique, is assumed to be another version of an educational justification of a hegemonic and unjust global Western regime. The third critique focuses on the epistemological preconditions of GCE, which assumes that GCE relies on a particular, culturally embedded 'Western epistemology' perpetuating historically grown global educational and epistemic injustices by dominating and subjugating alternative epistemological approaches.

\section{Global Citizenship Education: A Universalist Conception}

GCE, in its broadest sense, can be understood as an educational response to different political, moral, economic, cultural, spiritual and environmental effects of globalization. GCE is an essentially contested umbrella term, which covers, among others, civics and human rights education, peace education, and education for sustainable development or intercultural learning. Different conceptions of GCE may have a stronger focus on these or other elements or weigh and interpret them in different ways. ${ }^{6}$ Thus, in many cases, there can be a considerable overlap between conceptions of civic education that focus on the national context of a pluralistic society and transnationally oriented forms of civic education, such as GCE (De Ruyter and Spiecker, 2008). A variety of differing conceptions and practices of GCE is deployed by governments, corporations and NGOs (UNESCO etc.) in formal (schools, teacher education etc.) as well as more informal settings (street work etc.). ${ }^{7}$ It is important to note that the idea of the world citizen, promoted by conceptions of GCE, is usually to be understood as an educational, ethical, political, legal and sociocultural ideal. Global citizenship (for instance, in a world state) does not yet exist as a legal category.

The conception of GCE, which the following argument relies on, is based on the idea of connecting the local, the everyday and the mundane with the global, the transcendent and the universal (Gaudelli, 2016). A typical object of GCE would constitute, for instance, an ordinary consumption good, such as a pair of jeans. Educators may discuss the question where and under what conditions the jeans were produced, where the cotton comes from and how the whole product came to the shop next door. By thinking about the supply chains and the often highly unequal working conditions and wages, which are involved in the production of a pair of jeans, students are automatically forced to both transcend their local or everyday perspective and connect the global with the local, and vice versa. A critical reflection on everyday beliefs in light of higher-order principles and the transcendence and transformation of these beliefs in the engagement with knowledge about and the awareness of global interdependencies is a central element of GCE, as understood here. According to Gaudelli, the habit that GCE,

6 See the overview in: Oxley and Morris, 2013.

7 See the different examples of GCE from across the world in: Gaudelli, 2016. 
as a form of everyday transcendence, aims to cultivate and encourage,

'is simply mindfulness about how the world is present in all material and relational interactions, a habitual way of thinking that actively works away from the way we tend to see ourselves in the world and towards the way that we need to perceive ourselves: from isolated to integrated, disconnected to interconnected and separated to inseparable' (ibid.: 163).

As a reconfiguration and transformation of self-, world and other relations in different dimensions (ethical, political, economic, aesthetic etc.), which try to capture and integrate the potentially limitless interconnections between the mundane and the transcendent and universal, GCE is an ideal of education that can never be fully realized. As a form of general education ${ }^{8}$ in and for a globalized world, GCE comprises a variety of more fine-grained and specific educational aims. Also, with respect to these aims, the central underlying educational idea is to connect the local with the global (and vice versa) by fostering, among others:

- an awareness and critical reflection of global economic, cultural and political interdependencies, a geopolitical analysis of inequalities that pervade the world society (such as economic domination organized through global financial institutions) as well as of their historical genesis (global and colonial history); a critique and contextualization of questionable universalistic validity claims (such as one-sided notions of progress and development);

- the differentiation and expansion of cognitive and ethical horizons of reference and significance, as well as a reflection on how one's own positionality and location influences the way one sees the world in order to promote personal (most importantly: critical self-reflection) and political autonomy ${ }^{9}$ (among others, informed participation in an emerging global public sphere) $;^{10}$

- knowledge and understanding of the changing and dynamic dimension of 'cultures,' traditions and different local perspectives (e.g., on history); knowledge about international politics and institutions;

8 I am aware of the difficulties in operationalizing these notions in the context of a competence framework (see the discussion about the problems concerning the operationalization of the notion of 'global competence' in: Sälzer and Roczen, 2018). Nevertheless, even though these difficulties are also rooted in different notions of global justice employed by transnational organization, neither do these difficulties pose insurmountable problems to a normative conception of GCE as a form of general education, nor is such a conception necessarily bound to rely on a competence framework.

9 See the argumentation of Danielle Zwarthoed in this issue.

10 On the role of the Internet in fostering the emergence of a global public sphere and a global democracy, see: Wegerif, 2018. 
- cosmopolitan and democratic attitudes and virtues: openmindedness, acceptance and (at least) toleration of 'diversity,' which are conducive to participation in transnational forms of cooperation;

- knowledge and acceptance of basic, universally valid legal, moral and political principles (most importantly, human rights); ${ }^{11}$

- universalist forms of identification as aglobal citizen, which transcend different forms of nationalism, but are not per se incompatible with more local forms of identification (for instance, an identification as a European citizen). ${ }^{12}$

Global citizenship as an educational endeavour comprises moral, political, legal, cultural, economic, spiritual and environmental dimensions. It is certainly correct to assume that GCE is neither bound to a special subject (e.g., in public schools), such that it can be practically promoted via different means (for instance, by expanding the literary canon in schools and universities, by including authors from different traditions), nor able to be 'reduced to a specific set of educational practices' (Sant et al., 2018: 27). This does not involve the relativistic implication, however, that 'there is nothing like a correct approach to global citizenship that can be taught and learnt' (ibid.: 27). There can certainly be more or less 'correct' approaches to GCE, while the underlying values and principles of GCE can also be more or less valid (see my discussion in the following sections).

My conception of GCE has a strong cosmopolitan orientation ${ }^{13}$ in the sense that it relies on four types of universalism:

- Moral and legal universalism: GCE in central respects relies on a conception of human rights education ${ }^{14}$ and on an acknowledgement of the normative validity of equal human rights, as they are codified in the Universal Declaration of Human Rights, in the Convention on the Rights of the Child or also in the International Covenants of the UN. ${ }^{15}$

11 For instance: Brumlik, 2016. I think that all of these aims certainly can and should be ensured by all educational systems on our planet and that this is not mere abstract educational rhetoric. Nevertheless, one should keep in mind that the relation between normative ideals and concrete practices and policies is usually much more difficult and complex than what is usually taken into account (especially by philosophers). See: Scheunpflug, 2014; Ruggie, 2018.

12 See, for the case of a European identity: Fukuyama, 2018.

13 For an overview on different notions of cosmopolitanism, see: Brock and Brighouse, 2005; Kleingeld and Brown, 2019. For a conception of cosmopolitan education, see: Hayden, 2017; Wigger, 2019.

14 See, for instance: Gaudelli, 2016.

15 For an excellent discussion on the relation between children's rights and human rights, see: Krappmann, 2019. The acknowledgement of the validity of basic human rights does not rule out, that the interpretation of human rights will evolve in the future (for instance, in the form of more substantive social rights, as has been the case in liberal democracies). The fact that our understanding of human rights has historical origins and is subject to historical change, however, should not have the (relativistic) implication to teach them as principles with merely hypothetical validity: 'Currently, we believe that it is incompatible with human rights to be discriminated because of the color of one's skin, one day, however... '. I think that such a relativistic approach is certainly not a plausible and legitimate way to teach human rights. A detailed discussion of the question what should be taught as controversial (and what not) is, however, beyond the scope of this paper: see, for instance: Yacek, 2018. 
- Educational universalism: GCE relies on a conception of education, which is understood as an ideal of the critical reflection, transcendence and transformation of self-, world and other relations, as a universally valid educational standard. Such an autonomy-based conception is incompatible with strong particularist and communitarian notions of education and identity formation.

- Political universalism: GCE is based on a conception of transnational democratic education, ${ }^{16}$ which assumes that:

》Democratic self-determination is a basic human right.

»Personal and political autonomy is a coordinated and universally valid political and educational aim. ${ }^{17}$

» Increasing political and not just functional integration (beyond the nation state in the direction of a global democracy $)^{18}$ is, in the long run, necessary for a just global order and society. This conception is geared towards the identification with an emerging transnational political community and incompatible with forms of democratic education that only or primarily focus on the national and local context. $^{19}$

- Epistemological universalism: GCE is based on the assumption that a plurality of perspectives, forms of knowledge and knowledge acquisition is perfectly compatible with and can be integrated into a general and transcultural epistemology grounded in human nature and a shared objective reality, which is, in principle, accessible to everyone. This epistemological universalism is incompatible with strong versions of epistemological relativism or radical constructivism, as well as approaches that assume that epistemology is an essentially political enterprise, which is necessarily determined, for instance, by our cultural location or by power structures. It holds to the 'idea of a general compatibility' (Conrad, 2016: 198) as well as comparability of human experiences and therefore at odds with notions of 'radical difference,' which assume that it is impossible to actually understand the other. This also holds with respect to

16 See: Culp, 2018; 2019; Curren and Dorn, 2018.

17 I provide a detailed justification and defense of this view in: Drerup, 2018b.

18 This is not a logical and necessary political progression. I believe, however, that there is a logical educational progression from more local and national notions of (democratic) education concerning GCE. There is no other plausible way to deal with globalization and globality (in terms of the awareness of global interdependencies). Likewise, I agree with Brooks that global philosophy is the future (Brooks, 2013). This obviously also holds for the global philosophy of education.

19 Patriotic forms of democratic education are, however, not per se incompatible with a transnational conception of education. See, for instance: Papastephanou, 2008. 


\section{GLOBAL CITIZENSHIP EDUCATION, GLOBAL EDUCATIONAL INJUSTICE AND THE POSTCOLONIAL CRITIQUE}

conceptions of 'the radically different epistemic other,' which assume that the epistemic capacities of agents are fundamentally different, depending on the traditions or cultures in which they are at home or grew up. ${ }^{20}$

Taken together, all of these types of universalism (all of which are controversial) provide a general normative framework to make sense of GCE as an educational project. As a universalist political, moral and legal conception, GCE is embedded in a conception of global educational justice, which assumes that every child has a right to acquire the capacities, skills and dispositions necessary to become a citizen of the world. As an educational conception, however, it has to remain open concerning the exact interpretation of the relevant principles, the scope of transnational responsibilities that go along with them, as well as the relation between local and universal loyalties. ${ }^{21} \mathrm{~A}$ conception of GCE, which would leave no room at all when it comes to these questions, would have to face not only the charge of Western imperialism (cf. the third section), but also of indoctrination. ${ }^{22}$

Among the central justificatory problems that these different types of universalism have to face are the following: first, the question about where the universal comes from, where its origins lie and whether it is indeed universally valid or only within and relative to a particular tradition; second, the closely related question as to how the universal may be justified in the context of a highly pluralistic globalized world; and, third, how the universal may be connected with, embedded in and applied to the particular, without, however, oppressing the particular in the name of the universal. In what follows, I will neither be able to deliver a comprehensive justification ${ }^{23}$ nor a comprehensive defence of these four types of universalism against all potential counterarguments and

20 I discuss and criticize these positions in more detail below.

21 Thus, educators (especially in public school systems) should not, for instance, directly teach a strong version of cosmopolitanism.

22 This is a problem that is often overlooked in conceptions of social and global justice education; see: Asbrand and Scheunpflug, 2014; Overwien, 2016; Yacek, 2017. For an analysis of the concept of indoctrination, see: Drerup, 2018a. Nevertheless, I think that the core aspects of the conception of GCE can be defended against this charge (also due to the strong focus on both personal and political autonomy).

23 The position that I defend could be described as global liberal perfectionism, which assumes that human rights can be justified with reference to the objective positive consequences that having the status of a bearer of rights has for human beings and their well-being. Likewise, it assumes that it is objectively better for children and their well-being to be able to critically reflect on their inherited doctrines instead of staying heteronomous agents. I am sceptical concerning neutralist, political liberal approaches, because they allow for too much educational as well as ethical diversity (both on a local and a global level). They are therefore compatible with harms and impairments of children and their well-being and autonomy, which are - from a liberal perfectionist point of view - objectively wrong and illegitimate. Due to reasons of space in what follows I cannot discuss the many specific problems a liberal perfectionist position faces, for instance with respect to the relation between different traditions and communities, parental authority and children's autonomy. The moral, legal, political, educational as well as epistemological universalisms mentioned above are grounded in a conception of a universally shared human nature, which is not radically different among individuals around the world. Such a more substantive justification is in potential tension, but not necessarily incompatible, with a discourse-theoretic or democratic justification of human rights (for instance, see: Benhabib, 2016) and with the historicization of central normative principles (see: Gutmann et al. 2018). 
critiques. My argumentative aim is much more modest. I only want to show and argue that my universalist conception of GCE can be defended against some of the most prominent critiques, which, among others, have been put forward by postcolonial scholars.

\section{GCE and the Elitism Charge}

The critique of 'cosmopolitan elites' has been a recurrent theme in recent political debates and an important political strategy especially of right-wing political movements and parties. ${ }^{24}$ In line with this critique, sociologists tend to explain contemporary social and political conflicts in terms of a clash between cosmopolitan and globally minded groups and other socio-economic classes or milieus (Reckwitz, 2017; Zürn and De Wilde, 2016). ${ }^{25}$ While the former can indulge in the luxury of living 'transnationally oriented lifestyles,' the latter are more focused on their 'local life' and tend to make sense of their political situation by resorting to essentialist notions of culture. Living the life of a 'global citizen,' according to this perspective, is a question of prestige, social distinction and cultural capital in Bourdieu's sense (Krämer, 2018; Baumann, 1996). Enjoying the opportunities offered by globalization, the global citizen is today in New York and tomorrow in Kinshasa; she is culturally competent, well-educated and financially well off. Global citizenship, according to this critique, is thus nothing more than the project of an emerging highly exclusive international class (often primarily based in Western countries), which has shared educational experiences, cultural codes and employment practices.

In line with this, it may be assumed that the 'long-standing trajectory of global learning being an elite education' (Gaudelli, 2016: 119) results in an education for people 'who have more in common with each other than with their fellow citizens' (Fahrmeier, 2007: 232). In common with earlier notions of citizenship (Gosewinkel, 2016), GCE, being tied to processes of social exclusion, is expressive of (world) societal inequalities and not applicable to the experiences of ordinary citizens in most societal contexts. If you are illiterate and unemployed, you will obviously have more pressing problems than thinking about central topics of GCE (such as colonial history: Pike, 2008: 44). Moreover, empirical social research clearly shows that many (if not most) citizens in Western societies do not even have an adequate knowledge or understanding of local and national

24 In light of the fact that the critique of elites is certainly among the most important, and perhaps the most effective, political strategies, it is rather surprising to see that a political and economic 'global elite', which meets in Davos etc. as envisaged by right-wing and also left-wing critiques, does not exist. Empirical social research on elites, on the contrary, indicates that political and economic elites still have a much more national orientation when it comes to the location of their workplace and also with respect to longer living experiences in other countries. The proportion of elites who actually have such experiences and work outside of their country of birth is still a minority; see: Hartmann, 2018. For an analysis of the interrelationships between processes of internationalization and the formation of elites, which takes into account the competition between national and international elites as well, see: Zymek, 2016.

25 For a critique of culturalist explanations of contemporary political conflicts, which both takes socioeconomic and cultural factors into account, see: Manow, 2019. 


\section{GLOBAL CITIZENSHIP EDUCATION, GLOBAL EDUCATIONAL INJUSTICE AND THE POSTCOLONIAL CRITIQUE}

politics (see the overview in: Brennan, 2016). The aims of GCE, such as the provision of knowledge about the history of colonialism, consequently seem to be both elitist and overly demanding. Thus, one may wonder whether some 'citizens may not have any desire to become world citizens and do not need to, because their scope is relatively limited' (De Ruyter and Spiecker, 2008: 360).

The elitism charge constitutes a powerful and important critique of GCE. It suggests that GCE is not just expressive of global educational injustices but given the often-problematic ways elites tend to reproduce and recruit themselves (see: Hartmann, 2018; Anderson, 2007) - also perpetuates these injustices. ${ }^{26}$ I think that these observations are certainly, at least partly, on point and that the critique is sociologically to a certain extent correct. A 'global orientation,' as is indicated by empirical social research, will often be more common among the economically well off ${ }^{27}$ and in particular educational milieus. ${ }^{28}$ Likewise, there are definitely plenty of reasons to criticize elites and elitist conceptions of civic education, both on a more national (Merry, 2018) and on a more transnational level (Hartmann, 2018).

Nevertheless, one should be careful to distinguish between the social genesis of a particular ideal and orientation and the educational and political legitimacy of the claims and aims that go along with this. This is one of the reasons why it is wrong to associate GCE with a particular elitist way of life or an elite education. From an educational standpoint, it should be clear that the global elite should cultivate the values that are central to GCE, but that GCE, despite many socio-economic obstacles, can in principle be taught and practised in all kinds of educational contexts. ${ }^{29}$ There are no specifically educational arguments that speak against the possibility of offering education about human rights or colonial history in, for instance, the slums of Mumbai. GCE as such is not overly demanding or elitist, and the fact that many citizens fail to conform to GCE as an ideal does not render this ideal obsolete - on the contrary. As Gaudelli puts it:

'GCE has shifted from an elite-oriented education to a broad scale program. GCE is even more vital to students at the economic margins

26 Moreover, it is sometimes claimed that, with particular respect to the educational system, a transnational orientation is explicitly displayed by those elites who primarily have an interest in excellence and competitiveness in global markets. See: Gonon, 2018.

27 There are many potential reasons for this, such as access to educational and cultural goods from different traditions as well as the economic means to travel or even to cultivate an 'international' lifestyle.

28 There seems to be, for instance, a strong empirical correlation between a cosmopolitan orientation and the level of education: Mau, 2006; Merkel, 2017; Reckwitz, 2017. Apart from the fact that the educational and political validity of the aims of GCE cannot simply be inferred or disqualified by the findings of sociological research, one should be also careful not to generalize these results in the sense that it is (obviously) perfectly possible to develop cosmopolitan orientations without belonging to an educational, political or economic elite. According to a recent study, for instance, nearly one in two people (49\%) across 14 tracking countries see themselves more as global citizens, than citizens of their country (Globescan 2016).

29 See, for instance, the examples in: Gaudelli, 2016; Appadurai, 2013. 
of society since those students are less likely to have the ability to insulate themselves from adverse conditions of living in a hypernetworked era of fast capitalism that disproportionally harms people at the economic margins' (Gaudelli, 2016: 154).

GCE thus should not be identified with an elite education, but understood as a means of combatting global educational, economic and political injustices, among others, in the form of a general education, also of the elites (cf. Morton in this special issue).

Moreover, especially because the very concept of 'elite' recently became somewhat of a dirty term, one should also be aware of the important (and in many cases valuable) historical and contemporary role of elites in transcending particularist orientations (e.g., in the 19th century from the village to the city to the nation state, and to supranational institutions in the 21st century; Habermas, 2018), in articulating global political issues in emerging transnational public spheres and in implementing democratic institutions. ${ }^{30}$ Many forms of social, ideological and normative 'trickle down' from elites to other milieus can be evaluated positively from an educational and political standpoint. Thus, even if GCE is also an elite project ${ }^{31}$ (at least in the present moment), this does not make it illegitimate or problematic per se.

Elites are, to a certain extent, a fact of life in every political system and one should be careful to not uncritically adopt the usually anti-cosmopolitan rightwing critique of elites. This critique (as well as political strategy) suggests that all elites are somehow problematic, irrespective of the ideals that they defend. ${ }^{32}$ While there are plenty of reasons to be critical of elites (who, for instance, tend to always find new transnational ways to avoid paying taxes), ${ }^{33}$ it should also be clear that it is certainly not impossible to distinguish between 'good' (or better) elites and 'bad' (or worse) elites. ${ }^{34}$ It would be ethically and politically somewhat strange to, for instance, assume that Gandhi, Aurobindo or Habermas should be subsumed in the same category as Dugin, Al Suri or Heidegger. It is therefore rather one-sided to describe the promotion of different forms of international solidarity, of cosmopolitan attitudes or of transnational forms of

30 For the 19th century, see: Richter, 2017.

31 One should acknowledge, for instance, that the academic debate about GCE is obviously - nolens, volens - an elitist debate. This is, to a certain extent, unavoidable, and may have differing intentions: 'Because this book is written with a political pedagogical purpose, I decided not to write only for the cosmopolitan elite but for anyone who is struggling to make sense of global citizenship education and education for sustainable development' (Torres, 2017, x).

32 See, the defenses of: Schmoll, 2019 and Strenger, 2019. Schmoll and Strenger make a convincing case for the claim that elites are neither per se incompatible with a democratic and liberal order nor can such an order survive without elites that are disposed and willing to defend it.

33 While there are certainly several reasons to be critical of many contemporary political and economic global elites, this should be understood as another powerful rationale for and not against GCE.

34 Apart from the fact that even postcolonial scholars were criticized as elitist due to their focus on 'high theory' (Castro Varela and Dhawan, 2015), one should also remember that, in many cases, the most important criticisms of colonialism have often been voiced by transnationally oriented elites (see: Mishra, 2013). 
democratisation as merely being expressive of attempts of a 'transnational reeducation' of ultimately self-serving neoliberal elites. ${ }^{35}$ The central problem is not that elites exist, but rather that bad elites are in many cases much more influential than good elites (Hartmann, 2018)..$^{36}$

To conclude: While a (self-)critical conception of GCE should integrate a critique of its sociohistorical origins and its contemporary forms of social dissemination, neither its origins nor its dissemination in a given social context should be equated with its scope of validity. Thus, it can be acknowledged that the critique according to which GCE is an elite ideal can be substantiated by empirical evidence and is, at least to a certain extent, sociologically plausible. Nevertheless, the critique is wrong from an educational perspective and when it is applied to the educational and political legitimacy of GCE. GCE is not an elitist ideal in the sense that it is reserved for any particular class or milieu or for the purpose of promoting the narrow self-interest of certain elites. Instead, it is to be understood as an educational means of approaching an increasingly globalized world, a way that is and should be open, in principle, to every human being.

\section{Global Citizenship Education, the West and the Rest}

In the context of colonial regimes, 'Western education' was usually taken as an expression of the alleged superiority of the colonizers and served as a powerful instrument of colonial domination (Reinhard, 2018). A second critique assumes that GCE constitutes a reproduction and perpetuation of 19th- and 20th-century educational justifications and manifestations of colonialism and imperialism. GCE 'discourse' is thus assumed to be deeply entangled with world societal hierarchies and inequalities, which are used to justify different contemporary forms of neo-imperialism (cultural, ethical, moral, political, economic etc.) in the name of 'education.' According to this critique, GCE, as a genuinely Western project, is based on an arbitrary extrapolation of particular 'Western values' (personal autonomy, individualism, human rights, democracy and liberalism), conceptions of rationality (such as 'instrumental rationality') and the self (such as the 'unencumbered self') in relation to other social and cultural contexts and is therefore pseudo-universalist, neo-imperialist and intolerant towards other traditions (see, for instance: Mignolo, 2009; Lee, 2014; Mouffe, 2015; Dill, 2015; Wischmann, 2018). As 'the latest version of the long march of the Enlightenment ideal of the liberated, tolerant self in Western liberal democracies' (Dill, 2015: 100), GCE seems to be grounded in a naive universalism, which projects its own standards on the world and thereby follows the same deeply unjust logic

35 See the critique of: Streeck, 2017.

36 In some (rare) cases, it will be not easy for contemporary (but not future) agents to detect good elites or bad elites. What counts as a good elite will, in the end, depend on the values that one defends (on this problem, see: Miller, 2013). 
as colonial regimes. In what follows, I will argue that a universalist conception of GCE is not incompatible with reasonable forms of postcolonial critiques concerning the misuse of different forms of universalism and that, on the contrary, the latter should be considered as a central aspect of GCE.

To begin with, the critique that GCE relies on genuinely Western values and concepts tends to overestimate an alleged consensus within the 'Western tradition' (e.g., the debates between defenders of liberalism vs. communitarianism, political liberalism vs. liberal perfectionism) and operate with a highly simplified and essentialist idea about the nature of the 'Western tradition'. 37 'Western thought is diverse and no longer neatly distinguishable from alternative traditions. There are no easy boundaries between the "West" and "the rest"' (Enslin and Horsthemke, 2015: 1168). While this problem has also been acknowledged by postcolonial scholars, who criticise the dichotomy between 'The West and the Rest' ${ }^{8}$ and at the same time tend to rely on the ideas of both Western and non-Western thinkers and traditions (Loomba, 2015), the tendency to evoke simplified constructions of the 'West,' the 'Western tradition' or 'Western values,' in opposition to, for instance, the 'East,' can also be explained historically. As Mishra puts it:

'This meant that the greater the scale of humiliation by the West, the more intense was the desire to posit an idealized image of the East. Nevertheless, Tagore and Liang Qichao represented a strong early trend, still visible today, of Asian intellectuals defining Western modes of politics, economics, science and culture as inhumanly utilitarian' (Mishra, 2013: 254).

Even though historically and politically understandable, it nevertheless remains the case that these reductionist descriptions of the 'West' and the accompanying simplistic equations (universalism=Western=imperialism etc. ${ }^{39}$ ) rely on rather spectacular simplifications, which should play neither a role in contemporary philosophical and scientific debates about GCE nor in any practical programmes and conceptions of GCE. ${ }^{40}$

While these critiques overestimate the consensus in the 'Western tradition,' at the same time, they tend to underestimate the dynamic global flow and circulation of ideas. Democracy (Sen, 2005) or toleration (Nederman, 2012), for instance, are certainly not exclusively Western ideas, and it is a central desideratum of GCE to develop an awareness of the historical interconnections between different traditions. Postcolonial critiques themselves are, in many cases, more

37 For a critique of exclusivist and narrow interpretations of the metaphor of the 'West,' see: Appiah, 2018.

38 See the classical critique of: Stuart Hall, 1992.

39 Cf. the critique of these types of critiques by: Dübgen, 2017.

40 As Said has put it: 'The fact is, we are mixed in with one another in ways that most national systems of education have not dreamed of' (Said, 1994: 426). 


\section{GLOBAL CITIZENSHIP EDUCATION, GLOBAL EDUCATIONAL INJUSTICE AND THE POSTCOLONIAL CRITIQUE}

or less innovative reproductions of rather traditional forms of 'Western selfcritique,' as they were voiced, among others, by critical theory and different versions of communitarianism (cf. Sandel's critique of the 'unencumbered self,' or critiques of 'instrumental rationality' put forward by Horkheimer, Adorno and others, whose positions were also criticised as Eurocentric; Said, 1994; Allen, 2017). Thus, it should be noted that democracy and human rights are not universally accepted ideals in the West, nor do they 'belong' to a particular 'tradition' or geographical place at all:

'Or, to put it another way, what made Enlightenment ideas truly universal was that they became weapons in the hands of those who fought Western imperialism [...]. The ideals of liberty, equality, democracy and rights are not specific to the West. They are applicable to Haitans, to Indians and to South Africans' (Malik, 2014: 332).

Thus, even if the aims and normative underpinnings of GCE are also rooted in 'Western tradition,' this makes them neither inapplicable to other contexts nor per se illegitimate, Eurocentric or neo-colonialist (Culp, 2019). On the contrary, historical critiques of colonialism in many cases relied on universal values (such as human rights), while prominent critics of colonialism (such as Tagore) were often defenders of universalist and cosmopolitan ideals (Mishra, 2013). Therefore, it should be remembered that 'the denial of Enlightenment ideals, not their assertion, characterised colonialism and imperialism' (Butcher, 2018: 20). ${ }^{41}$

While there is always the danger that a universalist conception of GCE may become 'ethnocentric, ahistorical, depoliticized, paternalistic, salvationist and triumphalist' (Andreotti and De Souza, 2012: 1), and while there are ample historical reasons to be sceptical about every kind of universalist 'Western triumphalism' (for instance, in the name of human rights: Joas, 2015; or a developmentalist conception of progress; Allen, 2017), it is nevertheless important to bear in mind that the potential misuse of certain educational and political ideals does not make these ideals illegitimate per se. It is perfectly reasonable to criticise, for instance, the misuse of Mill's and Locke's conception of autonomy and rationality (Arneil, 2012) as well as racist elements in Kant's and Hegel's notion of education (Wischmann, 2018). To deduce from these historical examples, however, that the very ideas of autonomy, rationality or 'Bildung' are somehow essentially contaminated with colonial claims for domination is a highly questionable non-sequitur. The ambivalence of almost every educational and political idea and ideal one may think of is rooted in the fact that they may be used both for the justification of illegitimate forms of

41 Butcher adds: 'This is reversed in decolonial theory' (ibid.) 
domination and for emancipation. To ignore this ambivalence inevitably leads to a form of moralistic and dogmatic essentialism.

Moreover, it seems problematic that postcolonial critiques of universalism often do not make the normative underpinnings of their critique sufficiently explicit. ${ }^{42}$ They tend to invest a lot of energy in criticizing Western ideals, but remain relatively silent concerning alternative normative conceptions that may be educationally and politically feasible in an increasingly integrated and globalized world. ${ }^{43}$ These critiques are therefore in danger of (unintentionally) providing relativistic arguments for questionable forms of particularism (for instance, as promoted by dictatorships) and of not sufficiently taking into account the emancipatory potential of different forms of universalism (Wright, 2012). It is, for instance, unclear why the attempt to enable children to claim their rights should be regarded as a perpetuation of Western dominance. One may also wonder how a conception of 'hyper-self-reflexivity as a strategy that acknowledges everyone's complicities and investments in coercive and repressive belief systems' (Andreotti, 2010: 238), as it is advocated by some postcolonial scholars, could be made sense of or justified educationally, without resorting to a 'liberal' notion of the self or a liberal conception of personal autonomy. The postcolonialist critique thus is grounded in exactly the same values and ideals it criticises as expressions of Western Imperialism. The dismissal of these ideals, because they are assumed to be solely of Western origin, would as a consequence undermine central aspects and preconditions of the postcolonial critique as an educational project. ${ }^{44}$

In any case, the postcolonial critique is right in assuming that it is of pivotal importance for defenders of GCE to think about the particularities of their

42 This tendency seems to be rooted in the legacy of older versions of critical theory and also of certain branches of poststructuralism and postmodernism, which have been adopted by postcolonial scholars. I agree with Chakrabarty though, wo states that 'it would be wrong to think of postcolonial critiques of historicism (or the political) as simply deriving from critiques already elaborated by postmodern and poststructuralist thinkers of the West. In fact, to think this way would itself be to practice historicism, for such a thought would merely repeat the temporal structure of the statement, 'first in the West, and then elsewhere' (2008: 6). Nevertheless, I think that the political and theoretical alliance of some postcolonial theories with postmodern and poststructuralist theories is worth criticising (cf. for discussions on this question, see: Loomba, 2015; Reinhard, 2018), independently of where and by whom the respective theories were developed in the first place.

43 Andreotti, for instance, argues that educational encounters in the context of GCE should be 'framed around radical appeals to openness, to difference and to the negotiation of meaning, rather than around normative appeals to notions of impartial reasoning or ideas of democracy, freedom, rights and justice that are presented as universal' (Andreotti, 2010: 234). It seems to me that the construction of a dichotomy between these types of aims is not only artificial but also that the alternative aims Andreotti wants to promote are extremely vague and unclear (especially with respect to their application in an educational and therefore structurally asymmetric setting). See also, the critique of: Bechtum and Overwien, 2017.

44 This problem is regularly overlooked in the context of postcolonial theory. While the ideal of personal autonomy has strong roots in western philosophy and liberal societies, it can certainly also - in different variants and conceptions, which emphasize different aspects of autonomy - be found 'outside' the 'Western tradition.' For a more detailed and elaborate discussion of this problem, see Zwarthoed in this special issue. 
universalistic ambitions (Dill, 2015), as well as the problematic misuse of different forms of universalism or pseudo-universalism as a central topic of GCE. Universalism, to be sure, can have many particular roots in different traditions, and the application of universal values should not be understood as a simple exercise in deduction. That said, to think about these truisms, as well as multiple practical paths to citizenship through different local traditions, does not imply that we could or should give up on moral, legal, educational or political universalism in the context of GCE. Likewise, contemporary postcolonial scholars would also struggle to justify their own positions and critiques without, in one way or another, relying on universal values (such as human rights) and universalist validity claims. On a relativistic basis, which assumes that the validity of (allegedly) universal values is bound to a particular culture or society it is hardly possible to provide a plausible criticism of historically grown global educational and political injustices. Furthermore, the very assumption, that the imposition of certain values on another dominated culture is morally unacceptable and the belief that each person and cultural orientation deserve respect, itself seems to be transcultural and arguably about universal ideals as well. These universal ideals are also defended by critics of 'universalism,' who nevertheless tend to advocate them, irrespective of cultural boundaries, while applying them to such groups that arguably do not share them (see also, the argumentation in: Siegel, 2017). Moreover, in some cases, one has the impression that the postcolonial critiques of GCE are somewhat anachronistic, in the sense that they are built on premises concerning international power imbalances between the 'West' and the rest of the world, which were valid in the 19th or 20th centuries, but are not necessarily still valid today in the same way and to the same degree they were in the past (Baldwin, 2016). GCE, in the future, should thus be geared towards a universalist critique of different historical and contemporary (neo-)imperialist and (neo-)colonialist projects around the globe (Chinese, Russian, US etc.), instead of focusing solely on the 'West.'

The central problem and challenge of our times is not so much the protection of the particular from the universal, but rather the safeguarding of the universal from the particular. In an increasingly globalized world, in which different forms of moral and political particularisms thrive (such as authoritarian populisms), we need integrative, not separative educational ideals and political frameworks. As Edward Said has put it:

'What does need to be remembered is that narratives of emancipation and enlightenment in their strongest form were also narratives of integration not separation, the stories of people who had been excluded from the main group, but who were now fighting for a place 
in it' (Said, 1994: xxxiii).

To conclude, the normative reach of universalist educational and political ideals is not limited by their conditions of origin and their potential misuse does not make them illegitimate per se. On the contrary, a plausible justification of postcolonial critiques of global educational and political injustices will have to rely on universalist validity claims. Likewise, the critique of the Eurocentric legacy of GCE, as it is advocated by postcolonial scholars, should itself be understood as an integral part of a (self-) critical and universalist conception of GCE.

\section{Global Citizenship Education and Global Epistemic Injustice}

A third critique assumes that contemporary conceptions of GCE are based on a 'Western epistemology,' which is expressive of relations of power and domination that unjustly subjugate other 'epistemologies. ${ }^{45}$ GCE's underlying epistemology is therefore, according to this critique, geared towards the perpetuation of global educational and epistemic injustices.

It is a historical fact that, with respect to most colonial interactions, 'colonialism refracted the production of knowledge and structured the conditions for its dissemination and reception' (Loomba, 2015: 79). It did this, for example, via the educational system and via the production of scientific knowledge about the colonies. It is also undeniable that,

'certain traditional streams of Western thought have underpinned colonial and neo-colonial educational practices and systems. Historically they have lain at the heart of the cultural consequences of colonialism, in curricula that assumed the truth and the greater importance of Western forms of knowledge, denigrating and marginalizing so-called indigenous epistemologies and educational traditions' (Enslin and Horsthemke, 2015: 1167; see also: Mignolo, 2002; Kerner, 2012).

Foucault's view that knowledge and power are inseparable, as popularized in postcolonial studies, including Said's classic work Orientalism (1979), therefore seems to have a high plausibility with regard to colonial systems of knowledge and knowledge production. Since Said's thesis and the controversy it started (see: Loomba, 2015; Castro Varela and Dhawan, 2015; Heehs, 2003; Reinhard, 2018), a variety of other criticisms has been voiced against the 'epistemic violence' associated with 'European reason' or against epistemic ethnocentrism

45 The term 'epistemology' is used in the context of this debate not in the traditional philosophical sense as a theory of knowledge, but rather in a much broader sense, which seems to include every kind of belief system and 'way of looking at the world.' 


\section{GLOBAL CITIZENSHIP EDUCATION, GLOBAL EDUCATIONAL INJUSTICE AND THE POSTCOLONIAL CRITIQUE}

(Andreotti, 2011; Mignolo and Escobar, 2010; Andreotti, Ahenakew and Cooper, 2012; Castro Varela and Heinemann, 2016). In light of the colonial experience, all these critiques doubt the very possibility that a universal or general epistemology could exist, which would not be centred on the epistemic subjugation of other epistemologies. Instead, it is assumed that we need a plurality of equally valid, culturally embedded epistemological approaches. As Andreotti, referring to the position of Mignolo, has put it: 'Non-European epistemologies and ontologies are translated into universalised European epistemological parameters as inferior, less involved, primitive, erroneous or eccentric 'culturally tainted derivatives' (Andreotti, 2011: 385). According to this critique we should not just be sceptical concerning the project of a universal and transculturally oriented epistemology (or universal reason), we should also abandon the project of a 'compulsive description of reality-as-truth (which characterizes a project of neutral-universality' (ibid.: 395). The advocacy of an epistemological pluralism thus goes along with a postmodern scepticism concerning truth claims. As Andreotti and De Souza state: 'We define postcolonial theories as tools-forthinking rather than theories of truth. In this sense, we acknowledge their situatedness and partiality' (Andreotti and De Souza, 2012: 3). The (general or universal) argument that universalistic epistemological validity claims are inevitably bound up with power discourses and forms of domination, however, seems self-defeating. To begin with, it remains unclear whether this claim is true or whether it should be merely interpreted as an expression of political 'partiality' (and not as an epistemic validity claim), or even as an attempt by postcolonial scholars to assert epistemic domination. In this sense, these postmodern 'tools-for-thinking,' which abandon the idea of truth, do not seem very useful, at least when one wants to know what is or was actually going on (for instance, concerning a particular event in colonial history). While it is certainly plausible to assume that knowledge and power were inseparable in colonial regimes, it seems a rather questionable and anachronistic argument to generalize such a claim, as 'if education, knowledge, and forms of political and military oppression were a seamless continuity' (Sehgal Cuthbert, 2018: 2). Such an equivocation is not just conceptually problematic, but also politically so, because it stretches the relevant concepts (violence, oppression etc.) until they become pretty much meaningless.

A generalized identification of epistemic and scientific claims with the expressions of power relations, 'violence' or a particular 'culture' results in arbitrary and sometimes rather spectacularly arbitrary critiques (such as the claim that evidence-based education is neo-colonialist (Shahjahan, 2011)) and has problematic implications, when it is taken at face value in real-world 
political debates (for instance, when the Turkish education minister criticizes evolutionary theory as 'Eurocentric science'). How, one may wonder, should we criticize such an argument from the perspective of the postcolonial critique and its 'tools-for-thinking'?

Conrad states with reference to the example of history that there is, 'frequently only a thin line between the recognition of positionality and the affirmation of cultural incompatibility. [...] Radically alternative views however - the Aboriginal, the Native American, or the Chinese approach - can easily slide into new forms of centrism that make conversations beyond the boundaries of such native epistemologies difficult if not impossible' (Conrad, 2016: 174).

The equation of a critique of different belief-systems based on suitable criteria (reasons, evidence etc.) with hegemonic abuses of power by 'Eurocentric reason' thus provides a powerful multipurpose tool for anyone who is less interested in a rational discussion and in finding the truth than in enforcing his/her interests. It seems that a postmodern (political) epistemology, which cannot justify basic epistemic validity claims (e.g., concerning historical and social facts), degenerates into a simplistic ideology that cannot criticize totalitarian deformations of reality and is prone to justify oppressive educational and political regimes. Therefore, the assumption that a radical politicization (or even ethnicization) of 'epistemology' has somehow emancipatory effects (from the repressive effects of the universal etc.), which is shared by some postcolonial scholars, is not just epistemologically but also politically questionable. Such a position is not only prone to moralized and dogmatized forms of selfimmunization against critique, ${ }^{46}$ it even has the particularist implication that scholars who are not from the 'West,', 'should not aspire to speak too far outside of their assumed ontological and epistemological identities in search of universal truths' (Butcher, 2018: 18).

Thus, apart from the dubious monolithic constructions at work in the postcolonial critique ('Western epistemology'), it is not plausible to assume that science or a particular epistemology is essentially bound to geography: 'Conceptions of 'thought' as fixed geographically and in time can imprison us in analytical categories that overemphasize ahistorical conceptions of colonialism and culture' (Enslin and Horshemke, 2015: 1171; see also: Sen, 2005, 28). Postcolonial scholars should acknowledge that there is a crucial difference between the context of discovery of a certain idea and the context of

46 'In its advocacy of an ontological pluriverse and of diverse systems of knowledge, there is one knowledge claim that cannot be allowed - the claim that knowledge, from any source, ultimately, can aspire to be universal. In addition, presenting decolonialism as a moral and political imperative leaves little room for alternatives which become, $a$ priori, immoral' (Butcher, 2018: 21). 
its epistemological justification and that therefore ideas 'that have a universal veracity' obviously also may 'emerge from particular, contradictory and often (especially from the perspective of today) reactionary contexts' (Butcher, 2018: 17). It does not follow from this that the ideas themselves (such as evolutionary theory) are reactionary or only expressive of a 'Western will to power.' As Sen puts it:

'An epistemic methodology that sees the pursuit of knowledge as entirely congruent with the search for power is a great deal more cunning than wise. It can needlessly undermine the value of knowledge in satisfying curiosity and interest; it significantly weakens one of the profound characteristics of human beings' (Sen, 2005: 143).

The problem is that proponents of epistemological diversity, in particular, sometimes 'treat epistemological diversity itself somewhat uncritically, as if the critical evaluation of these diverse epistemological perspectives is impossible, undesirable,orinappropriate'(Siegel,2017:268). Celebrations of epistemological diversity in combination with a critique of Western epistemologies thus tend to turn into a form of 'epistemic prison mentality,' which assumes that members of other 'cultures' are radically different 'epistemic others,' who see the world in a radically different way, which is inevitably inaccessible to 'outsiders.' Along these lines Siegel states that:

the 'suggestion that different cultures or communities have their own, unchallengeable 'epistemological perspectives', such that what counts as knowledge or as acceptable research varies from group to group - so that a given research finding counts as knowledge, or as established, for men but not for women; or for African Americans but not for Anglo-Americans, Cuban Americans, Korean Americans or Haitian Americans; or for gay and lesbian but not heterosexual consumers of educational research - is equally incorrect philosophically and equally undermining of the very point of conducting or reading such research. So understood, the call for epistemological diversity is one that should be resisted by educational researchers' (ibid., 276).

The generalized claim that a universalist epistemology or particular research method is neo-colonialist and therefore reproduces global epistemic and educational injustices does not withstand critical scrutiny. Especially in their more extreme versions, these critiques tend to deteriorate into an epistemological version of cultural essentialism and identity politics, and hence into forms of thinking which a universalist conception of GCE aims to criticise and transcend. I agree with Conrad that this, 
'should not however discourage attempts to acknowledge positionality or render critical reflection on the structures of contemporary knowledge production less urgent. Decentering perspectives on the world and a decentering of our interpretations of the past (and the present: J.D.) remain crucial' (Conrad, 2016: 181).

A critical assessment of particularist conceptions of differing and allegedly mutually incompatible 'cultural epistemologies,' does not imply that interrelations between a particular epistemic practice, (neo-)colonial power relations and global injustices should not be discussed in the context of GCE, nor does it mean that epistemological and methodological diversity is not of value. On the contrary, it is a central desideratum of a universalist conception of GCE to construct a broad and diverse global educational canon (for instance, in the context of a 'global philosophy of education'), which is in principle accessible to everyone. The integration and acknowledgment of different perspectives and approaches, however, does not imply an uncritical celebration of everything. ${ }^{47}$ Instead, we should acknowledge that philosophical and scientific research is a democratic project (Merton, 1972) to which in principle everybody can contribute and hence access the plausibility of arguments as impartially and objectively as possible, independently of whom articulates them and where they originate. In the end, different forms of epistemic disagreement are not rooted in differing and allegedly mutually incompatible 'Western' or 'Eastern' epistemologies, but in disagreements between human beings, who are, from a truly humanistic, universal and global perspective, not that different.

\section{Conclusion}

In this contribution, I defended a universalist conception of GCE against three of its most prominent critiques. I argued that the elitism charge against GCE, even though partly plausible from a sociological point of view, is wrong from an educational perspective. GCE should not be equated with the lifestyle of a particular class or with an elitist education. Instead GCE should be

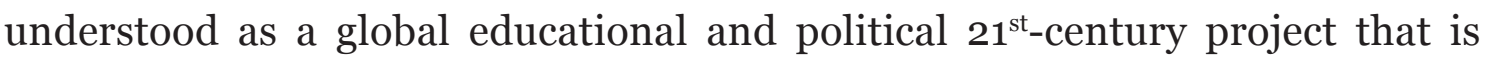
committed to establishing global educational and political justice and that can, in principle, be practiced everywhere in the world and by everyone. Moreover, I argued that the postcolonial critique that a universalist conception of GCE is based on genuinely 'Western values' and is therefore to be interpreted as the manifestation and justification of a contemporary form of (neo-)imperialism relies on questionable theoretical and empirical premises, which cannot be

47 Moreover, instead of cultivating a superficial anti-scientism or a radical politicization of epistemology, it should also be acknowledged that the methodological and epistemological standards of science provide the best strategies and instruments we have at our disposal to reach a (scientifically and thus methodologically) controlled 'truth.' This is especially noteworthy in times in which the anti-scientistic notion of post-truth has been 'openly embraced as a strategy for the political subordination of reality' (McIntyre, 2018: xiv.). 
upheld. This also holds for the critique that assumes that GCE is expressive of a 'Western epistemology' which is geared towards the subjugation of alternative epistemological approaches. I agree with Andreotti (2011) and other postcolonial scholars, however, that every plausible and historically informed conception of GCE will also have to incorporate central elements of postcolonial critiques. I hope to have provided some compelling arguments in support of the view that these critiques as well as the guiding principles of a (self-)critical conception of GCE cannot be adequately justified without recourse to universalist validity claims. ${ }^{48}$

Johannes Drerup

Professor

General educational science and educational theory

Technical University (TU) Dortmund.

email:johannes.drerup@tu-dortmund.de

\section{- the global justicenetwork}

48 I would like to thank the two anonymous reviewers for their constructive and helpful comments and suggestions. 


\section{Bibliography}

Anderson E (2007) Fair Opportunity in Education: A Democratic Equality Perspective, Ethics 117: 595-622.

Allen A (2017) Adorno, Foucault, and the End of Progress: Critical Theory in Postcolonial Times. In Deutscher P and Lafont C (eds). Critical Theory in Critical Times. New York: Columbia University Press: 183-207.

Andreotti V, Ahenakew C and Cooper G (2012) Equivocal Knowing and Elusive Realities: Imagining Global Citizenship Otherwise in Andreotti V and de Souza L (eds). Postcolonial Perspectives on Global Citizenship Education. New York; London: Routledge: 221-237.

Andreotti V (2010) Postcolonial and post-critical global citizenship education. In: Elliot G, Fourali C and Issler S (eds). Education and social change: Connecting local and global perspectives. London: Continuum International: 233-245.

Andreotti V (2011) (Towards) decoloniality and diversality in global citizenship education. Globalisation, Societies and Education, 9(3-4): 381-397.

Andreotti V and de Souza L (2012) Introduction: (Towards) Global Citizenship Education 'Otherwise.' In Andreotti V and de Souza L (eds) Postcolonial Perspectives on Global Citizenship Education. New York; London: Routledge: 1-6.

Appadurai A (2013) The Future as Cultural Fact. London; New York: Verso.

Appiah AK (1991) Is the Post- in Postmodernism the Post- in Postcolonial? Critical Inquiry, 17(2): 336-357.

Appiah AK (2018) The lies that bind. Rethinking identity. London: Profile Books.

Arneil B (2012) Liberal Colonialism, Domestic Colonies and Citizenship. History of Political Thought 23: 491-523.

Asbrand B and Scheunpflug A (2014) Globales Lernen. In Sander W (ed) Handbuch Politische Bildung. Schwalbach: ZpB: 401-414.

Baldwin R (2016) The Great Convergence. Cambridge, MA; London: Harvard University Press.

Barnett M (2017) Conclusion: The World According to Paternalism. In Barnett M (eds)

Paternalism without Borders. Cambridge: Cambridge University Press: 316-344.

Baumann Z (1996) Tourists and Vagabonds. HIS, Political Science Series 30: 3-15.

Bechtum A and Overwien B (2017) Kann postkoloniale Kritik Schule machen? Über ihre Grenzen und Potenziale für (entwicklungs-)politische Bildungsarbeit. In Burchardt HJ, Peters $\mathrm{S}$ and Weinmann $\mathrm{N}$ (eds) Entwicklungstheorie von heute -Entwicklungspolitik von morgen. Baden-Baden: Nomos: 59-85.

Benhabib S (2016) Kosmopolitismus ohne Illusionen. Berlin: Suhrkamp.

Brennan J (2016) Against Democracy. Princeton: Princeton University Press.

Brock G and Brighouse H (eds) (2005) The Political Philosophy of Cosmopolitanism. 


\section{GLOBAL CITIZENSHIP EDUCATION, GLOBAL EDUCATIONAL INJUSTICE AND THE POSTCOLONIAL CRITIQUE}

Cambridge: Cambridge University Press.

Brooks T (2013) Philosophy Unbound: The Idea of Global Philosophy. Metaphilosophy 44: 254266.

Brumlik M (2016) Kosmopolitische Moral im Zeitalter der Globalisierung: Menschenrechtliche Bildung und globale Erinnerungskultur. In Weyers S and Köbel N (eds) Bildung und Menschenrechte. Wiesbaden: Springer: 69-89.

Butcher J (2018) Questioning the Epistemology of Decolonise: The Case of Geography. Social Epistemology Review and Reply Collective 7/11: 12-24.

Castro Varela M and Dhawan N (2015) Postkoloniale Theorie: Eine kritische Einführung. Bielefeld: transcript.

Castro Varela M and Heinemann AB (2016) Globale Bildungsbewegungen Wissensproduktionen verändern. Zeitschrift für internationale Bildungsforschung und Entwicklungspädagogik, 39(2): 17-22.

Castro Varela M (2016) Postkolonialität. In Mecheril P (ed) Handbuch Migrationspädagogik. Weinheim, Basel: Beltz: 152-166.

Chakrabarty D (2008) Provincializing Europe. Princeton; Oxford: Princeton University Press.

Chandra-Milena D (2013) Überlegenheitsdenken fällt nicht vom Himmel. Postkoloniale Perspektiven Globales Lernen und Bildung für nachhaltige Entwicklung. Zeitschrift für internationale Bildungsforschung und Entwicklungspädagogik, 36(1): 26-33.

Conrad S (2016) What is Global History? Princeton: Princeton University Press.

Culp J (2018) Internationalizing Nussbaum's model of cosmopolitan democratic education. Ethics and Education 13(2): 172-190;

Culp J (2019) Democratic Education in a Globalized World. London; New York: Routledge.

Curren R and Dorn C (2018) Patriotic Education in a Global Age. Chicago; London: University of Chicago Press.

De Ruyter D and Spiecker B (2008) The World Citizen Travels with a Different View. In Peters M, Britton A and Blee H (eds) Global Citizenship Education. Rotterdam/Taipei: Sense publishers: 351-364.

Dill J (2015) The Longings and Limits of Global Citizenship Education. New York: Routledge.

Drerup J (2018a) 'Zwei und zwei macht vier.': Über Indoktrination und Erziehung. Diskurs Kindheits- und Jugendforschung, 1: 7-24.

Drerup J (2018b) Education for Democratic Tolerance, Respect and the Limits of Political Liberalism. Journal of Philosophy of Education, 52(3): 515-532.

Dübgen F (2017) Fortschritt im Widerstreit - Dekolonisierung als Kritik? Deutsche Zeitschrift für Philosophie 65(1): 163-173.

Enslin P and Horsthemke K (2015) Rethinking the Western Tradition. Educational Philosophy and Theory 47(11): 1166-1174. 
Fahrmeier A (2007) Citizenship: The Rise and Fall of a Modern Concept. New Haven: Yale University Press.

Fukuyama F (2018) Identity Politics. London: Profile Books.

Gaudelli W (2016) Global Citizenship Education, Everyday Transcendence. Oxford; New York: Routledge.

Globescan (2016) Global Citizenship a growing sentiment among citizens of emerging economies: Global Poll. Available at: https://globescan.com/wp-content/uploads/2016/04/ BBC_GlobeScan_Identity_Season_Press_Release_April\%2026.pdf (accessed 13 February 2020).

Gonon P (2018) Globalisierung als Herausforderung für die Schule (und Schultheorie). In Reichenbach R and Patrick Bühler P (eds) Fragmente zu einer pädagogischen Theorie der Schule. Weinheim: Beltz: 208-223.

Gosewinkel D (2016). Schutz oder Freiheit? Berlin: Suhrkamp.

Gutmann T, Laukötter S, Pollmann A and Siep L (eds) (2018). Genesis und Geltung. Tübingen: Mohr Siebeck.

Habermas J (2018). Sind wir noch gute Europäer? Die Zeit, 28: 43-44.

Hall S (1992) The West and the rest: Discourse and power. In Hall S and Gieben B (eds) Formations of Modernity. Cambridge: Polity Press: 275-331.

Hayden M (2017) The Process Matters: Moral Constraints on Cosmopolitan Education. Journal of Philosophy of Education 51(1): 248-266.

Hartmann M (2018) Die Abgehobenen. Wie die Eliten die Demokratie gefährden. Frankfurt; New York: Campus.

Heehs P (2003) Shades of Orientalism: Paradoxes and Problems in Indian Historiography. History and Theory, 42: 169-195

Heehs P (2008) The Lives of Sri Aurobindo. New York: Columbia University Press.

Hobson J (2017) Eurocentric Pitfalls and Paradoxes of International Paternalism: Decolonizing Liberal Humanitarianism 2.o. In Barnett M (ed) Paternalism without Borders. Cambridge: Cambridge University Press. 99-131.

Joas H (2015) Sind die Menschenrechte westlich? München: Kösel.

Kerner I (2012) Postkoloniale Theorien. Hamburg: Junius.

Kleingeld P and Brown E (2019) Cosmopolitanism. In Zalta EN (ed) The Stanford Encyclopedia of Philosophy (Winter 2019 edition). Available at: https://plato.stanford.edu/entries/ cosmopolitanism/ (accessed 23 February 2020).

Krämer G (2013) Von antirassistischen Denkverboten. Anmerkungen zur Rassismus-Debatte in der entwicklungspolitischen Bildung. Zeitschrift für internationale Bildungsforschung und Entwicklungspädagogik, 36(3): 32-34.

Krappmann L (2019) Menschenrechte und Kinderrechte. In Drerup J and Schweiger G (eds) 


\section{GLOBAL CITIZENSHIP EDUCATION, GLOBAL EDUCATIONAL INJUSTICE AND THE POSTCOLONIAL CRITIQUE}

Handbuch Philosophie der Kindheit. Stuttgart: Metzler.

Krämer K (2018) Sehnsucht nach dem nationalen Container. Zur symbolischen Ökonomie des neuen Nationalismus in Europa. Leviathan 46(2): 280-302.

Lee C (2014) Decolonizing global citizenship. In Isin E and Nyers P (eds) Routledge Handbook of Global Citizenship Studies. London; New York: Routledge: 75-85.

Liebel M (2017) Postkoloniale Kindheiten. Weinheim: Beltz.

Loomba A (2015) Colonialism/Postcolonialism. London; New York: Routledge.

Manow P (2019) Politischer Populismus als Ausdruck von Identitätspolitik? Über einen ökonomischen Ursachenkomplex. Aus Politik und Zeitgeschichte, 9-11: 33-40.

Mau S (2006) Nationalstaatliche Entgrenzung und kosmopolitische

Politisierung. WZB discussion paper 12. Available at: https://www.econstor.eu/

bitstream/10419/50264/1/526583266.pdf (accessed 23 February 2020).

Malik K (2014) The Quest for a Moral Compass. London: Atlantic Books.

McCarthy T (2009) Race, Empire, and the Idea of Human Development. Cambridge:

Cambridge University Press.

McIntyre L (2018) Post-Truth. Cambridge; London: MIT Press.

Merkel W (2017) Kosmopolitismus versus Kommunitarismus: Ein neuer Konflikt der Demokratie. In Harfst P, Kubbe I and Poguntke T (eds) Parties, Governments and Elites. Wiesbaden: Springer VS: 9-23.

Merry M (2018) Citizenship, Structural Inequality and the Political Elite. On Education. Journal for Research and Debate, 1(1). doi: 10.17899/on_ed.2018.1.1.

Merton R (1972) Wissenschaft und demokratische Sozialstruktur. In Weingart P (eds) Wissenschaftssoziologie 1. Wissenschaftliche Entwicklung als sozialer Prozeß. Frankfurt a.M.: Athenäum Fischer Verlag: 45-59.

Mignolo W (2002) The Geopolitics of Knowledge and the Colonial Difference. The South Atlantic Quarterly, 101(1): 57-96.

Mignolo W (2009) Who speaks for the 'Human' in Human Rights? Hispanic Issues On Line 5(1): 7-24.

Mignolo W and Escobar A (eds) (2010) Globalization and the Decolonial Option. Oxford; New York: Routledge.

Miller D (2011) The idea of global citizenship. Nuffield's Working Papers Series in Politics. Available at: https://www.nuffield.ox.ac.uk/politics/papers/2011/David\%20Miller_ working\%2opaper\%202011_02.pdf (accessed 6 December 2018).

Miller D (2013) Lea Ypi on global justice and avant-garde political agency: some reflections. Ethics \& Global Politics, 6(2): 93-99.

Mishra P (2013) From the Ruins of Empire. London: Penguin. 
Mouffe C (2015) Agonistik. Bonn: bpb.

Nederman C (2012) Toleration in a new key: historical and global perspectives. In Edyvane D and Matravers M (eds) Toleration Re-Examined. London; New York: Routledge: 69-82.

Oelkers J (2018) Autoritarismus und liberale öffentliche Bildung. Zeitschrift für Pädagogik 64(6): 728-748.

Overwien B (2016). Globales Lernen und politische Bildung - eine schwierige Beziehung? Zeitschrift für internationale Bildungsforschung und Entwicklungspädagogik, 39(2): 7-11.

Oxley L and Morris P (2013) Global Citizenship: A Typology for Distinguishing its Multiple Conceptions, British Journal of Educational Studies 61(3): 301-325.

Papastephanou M (2008) Cosmopolitanism: With or Without Patriotism. In Peters M, Britton A and Blee H (eds) Global Citizenship Education. Rotterdam; Taipei: Sense publishers: 169-186.

Pike G (2008) Citizenship Education in Global Context. Brock Education, 17: 38-49.

Pitts J (2005) A Turn to Empire. Princeton; Oxford: Princeton University Press.

Reckwitz A (2017) Die Gesellschaft der Singularitäten. Berlin: Suhrkamp.

Reinhard W (2018) Die Unterwerfung der Welt. Bonn: BpB.

Richter H (2017) Moderne Wahlen. Eine Geschichte der Demokratie in Preußen und den USA im 19. Jahrhundert. Hamburg: Hamburger Edition.

Ruggie J (2018) Die soziale Konstruktion der Leitlinien für Wirtschaft und Menschenrechte der Vereinten Nationen. Leviathan 46(1): 6-36.

Sälzer C and Roczen N (2018) Die Messung von Global Competence im Rahmen von PISA 2018. Zeitschrift für Erziehungswissenschaft 21: 299-316.

Sandel M (1998) Liberalism and the Limits of Justice. Cambridge: Cambridge University Press.

Sant E, Davies I, Pashby K and Shultz L (2018) Global Citizenship Education. London:

Bloomsbury.

Said E (1979) Orientalism. New York: Vintage Books.

Said E (1994) Culture \& Imperialism. New York: Vintage Books.

Shahjahan R (2011) Decolonizing the evidence-based education and policy movement: revealing the colonial vestiges in educational policy, research, and neoliberal reform. Journal of Education Policy, 26(2): 181-206.

Scheunpflug A (2014) Globales Lernen und die Debatte über Postkolonialität. Zeitschrift für internationale Bildungsforschung und Entwicklungspädagogik, 37(4): 31-32.

Schmoll H (2009) Lob der Elite. München: Beck.

Sehgal Cuthbert A (2018) Politics and Education: a need for stronger boundaries, (unpublished manuscript).

Sen A (2005) The Argumentative Indian. New York: Farrar, Straus and Giroux. 


\section{GLOBAL CITIZENSHIP EDUCATION, GLOBAL EDUCATIONAL INJUSTICE AND THE POSTCOLONIAL CRITIQUE}

Sen A (2006) Identity and Violence. London: Penguin.

Strenger, C (2019) Diese verdammten liberalen Eliten. Berlin: Suhrkamp.

Torres C (2017) Theoretical and Empirical Foundations of Critical Global Citizenship Education. New York; London: Routledge.

Tully J (2008) Two Meanings of Global Citizenship Education: Modern and Diverse. In Peters M, Britton A and Blee H (eds) Global Citizenship Education. Rotterdam; Taipei: Sense publishers: $15-40$.

Siegel H (2017) Education’s Epistemology. Oxford: Oxford University Press.

Streeck W (2017) Die Wiederkehr des Verdrängten als Anfang vom Ende des Kapitalismus. In Geisselberger H (ed) Die große Regression. Berlin: Suhrkamp: 253-274.

Wegerif R (2018) New Technology and the Apparent Failure of Democracy: An Educational Response. On Education. Journal for Research and Debate, 1(1).

Wigger L (2019) Kosmopolitismus - Anmerkungen zu einem Ideal historisch-politischer Bildung. Vierteljahrsschrift für wissenschaftliche Pädagogik, 95: 247-271.

Wischmann A (2018) The absence of 'race' in German discourses on Bildung. Rethinking Bildung with critical race theory. Race, Ethnicity and Education 21(4): 471-485.

Wohlfahrt G (2018) Global Citizenship Education (GCED) in Myanmar. Am Beispiel eines Projekts der internationalen Bildungszusammenarbeit. Zeitschrift für internationale Bildungsforschung und Entwicklungspädagogik, 41(1): 23-28.

Wright C (2012) Postcolonial Cosmopolitanisms: Towards a Global Citizenship Education based on 'Divisive Universalism.' In Andreotti V and de Souza L (eds) Postcolonial Perspectives on Global Citizenship Education. New York; London: Routledge: 47-67.

Yacek D (2017) Transformation and Education. A Philosophical Inquiry. Columbus, OH: Ohio Link.

Yacek D (2018) Thinking controversially: The psychological condition for teaching controversial issues. Journal of Philosophy of Education, 52(1): 71-86.

Zürn M and de Wilde P (2016) Debating Globalization: Cosmopolitanism and Communitarianism as Political Ideologies. Journal of Political Ideologies, 3: 280-301.

Zymek B (2016) Stichwort: Internationalisierungsprozesse und Elitebildung. Zeitschrift für Erziehungswissenschaft, 19: 671-688. 